Provided for non-commercial research and education use. Not for reproduction, distribution or commercial use.

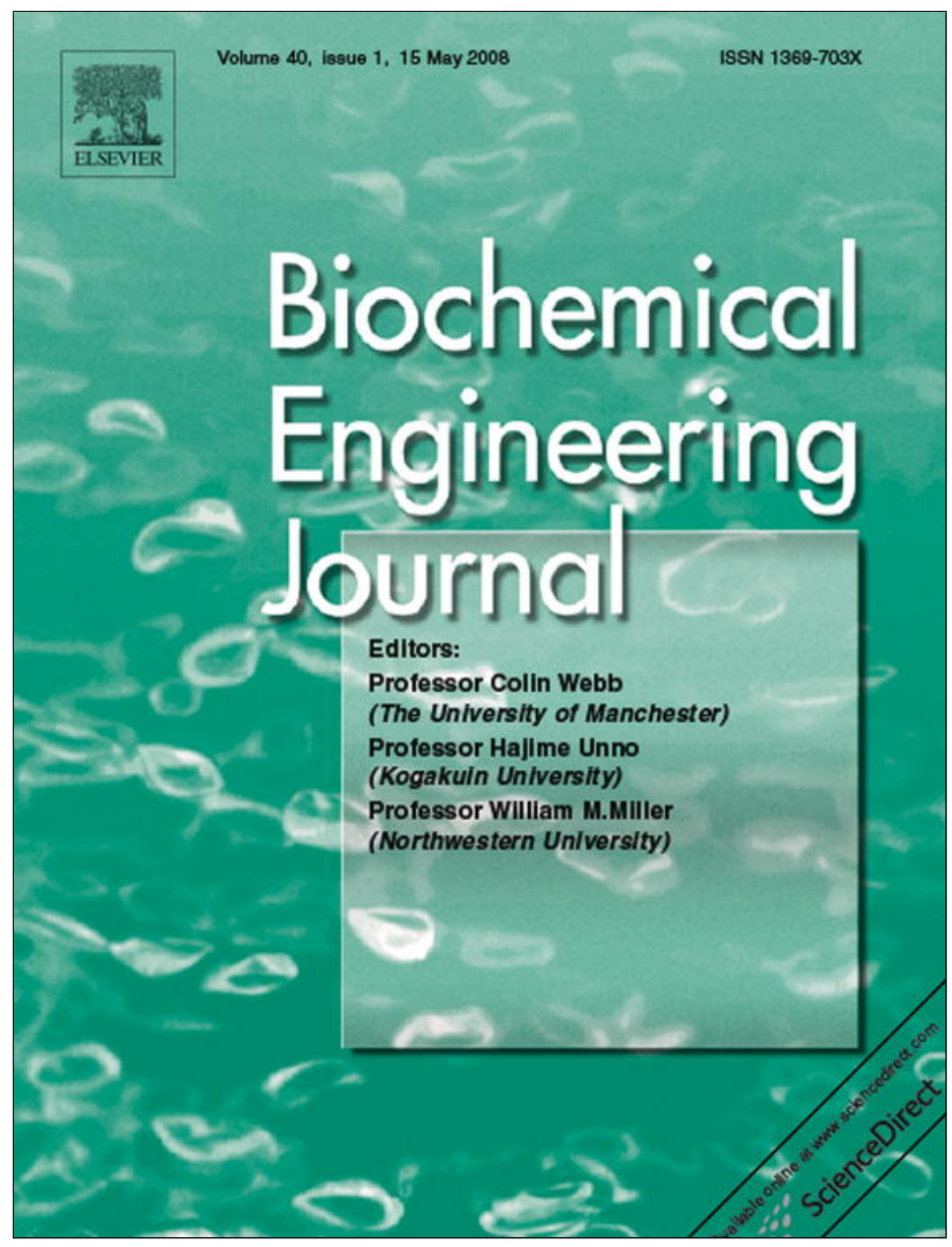

This article appeared in a journal published by Elsevier. The attached copy is furnished to the author for internal non-commercial research and education use, including for instruction at the authors institution and sharing with colleagues.

Other uses, including reproduction and distribution, or selling or licensing copies, or posting to personal, institutional or third party websites are prohibited.

In most cases authors are permitted to post their version of the article (e.g. in Word or Tex form) to their personal website or institutional repository. Authors requiring further information regarding Elsevier's archiving and manuscript policies are encouraged to visit:

http://www.elsevier.com/copyright 


\title{
Biomass production and carbon dioxide fixation by Aphanothece microscopica Nägeli in a bubble column photobioreactor
}

\author{
Eduardo Jacob-Lopes, Lucy Mara Cacia Ferreira Lacerda, Telma Teixeira Franco* \\ School of Chemical Engineering, State University of Campinas, UNICAMP, P.O. Box 6066, 13083-970, Campinas-SP, Brazil \\ Received 2 March 2007; received in revised form 29 October 2007; accepted 18 November 2007
}

\begin{abstract}
The objective of the present study was to evaluate the growth kinetics of Aphanothece microscopica Nägeli under different conditions of temperature, light intensity and $\mathrm{CO}_{2}$ concentration. The growth kinetics of the microorganism and carbon biofixation were evaluated using a central composite design, considering five different temperature levels $\left(21.5,25,30,35\right.$ and $\left.38.5^{\circ} \mathrm{C}\right)$, light intensities $(0.96,3,6,9$ and $11 \mathrm{klux})$ and carbon dioxide concentrations $(3,15,25,50$ and $62 \%)$. The results obtained showed the effects of temperature, light intensity and $\mathrm{CO}_{2}$ concentration $(p<0.05)$ on the photosynthetic metabolism of the microorganism. Response surface methodology was adequate for process optimisation, providing a carbon fixation rate to the order of $109.2 \mathrm{mg} \mathrm{L}^{-1} \mathrm{~h}^{-1}$ under conditions of $11 \mathrm{klux}, 35^{\circ} \mathrm{C}$ and $15 \%$ carbon dioxide, representing an increase of $58.1 \%$ as compared to the conditions tested initially.

(C) 2007 Elsevier B.V. All rights reserved.
\end{abstract}

Keywords: Carbon dioxide sequestration; Photobioreactor; Cyanobacteria

\section{Introduction}

Innumerable research projects have suggested that the biofixation of $\mathrm{CO}_{2}$ by cyanobacteria in photobioreactors is a sustainable strategy, since carbon dioxide can be incorporated into the molecular structure of cells in the form of proteins, carbohydrates and lipids by way of photosynthetic reactions. The advantages of these processes are related to the greater photosynthetic efficiency of these systems when compared to higher plants, the resistance of these microorganisms to high carbon dioxide concentrations and the possibility of controlling the culture growth conditions. In addition, the biomass produced by the bioconversion of carbon dioxide allows one to obtain products of high added value, such as, fatty acids, biodiesel, biogas and organic fertilizers, as a function of the microalgal species used and the effluent to be treated [1-3].

According to Lee et al. [4] and Jacob-Lopes et al. [5], only a small fraction of the carbon dioxide injected into the photobioreactors is incorporated into the microalgal biomass. According to these authors, other products of photosynthetic metabolism, such as the formation of extracellular biopolymers, precipitates of chemical species such as carbonates and bicarbonates and

\footnotetext{
* Corresponding author.

E-mail address: franco@feq.unicamp.br (T.T. Franco).
}

volatile organic compounds (VOCs), are more highly represented in the carbon dioxide transformation processes of these systems, substantially increasing the fixation rates.

Aphanothece microscopica Nägeli is a cyanobacterium characteristic of the estuaries in southern Brazil, belonging to the family choroococaceae and forming blue-green colonies adapted for floating. It shows a macroscopic, amorphous structure with abundant, firm and rigid mucilage, and non-cylindrical ellipitical adult cells measuring 9.0-9.5 $\mu \mathrm{m} \times 4.0-4.2 \mu \mathrm{m}$, approximately 2.2 times longer than they are wider [6]. Previous studies have shown the potential of applying this microorganism in bioremediation and for the production of single-cell protein (SCP) [7-9].

Thus the objective of the present study was to evaluate distinct operational conditions for photobioreactors, expressed in terms of the temperature, light intensity and carbon dioxide concentration, aimed at maximizing carbon fixation in the cells of the cyanobacterium Aphanothece microscopica Nägeli.

\section{Materials and methods}

\subsection{Microorganism and culture medium}

Unialgal cultures of Aphanothece microscopica Nägeli (RSMan92) were originally isolated from the Patos Lagoon 


\begin{tabular}{|ll|}
\hline \multicolumn{2}{l|}{ Nomenclature } \\
$C_{\mathrm{c}}$ & percent carbon in the biomass $(\%)$ \\
$(\mathrm{L})$ & linear effect \\
$M_{\mathrm{CO} 2}$ & molecular weight of $\mathrm{CO}_{2}$ \\
$M_{\mathrm{C}}$ & molecular weight of carbon \\
$(\mathrm{Q})$ & quadratic effect \\
$R^{2}$ & coefficient of determination \\
$R_{\mathrm{C}}$ & carbon fixation rate $\left(\mathrm{mg} \mathrm{L}^{-1} \mathrm{~h}^{-1}\right)$ \\
$t$ & residence time in $t=n(\mathrm{~h})$ \\
$t_{0}$ & residence time in $t=0(\mathrm{~h})$ \\
$t_{\mathrm{g}}$ & generation time $(\mathrm{h})$ \\
$t_{\text {log }}$ & duration of logarithmic growth phase $(\mathrm{h})$ \\
$X_{\mathrm{m}}$ & maximum cell concentration $\left(\mathrm{mg} \mathrm{L}^{-1}\right)$ \\
$X_{0}$ & initial cell concentration $\left(\mathrm{mg} \mathrm{L}^{-1}\right)$ \\
$X_{1}, X_{2}$, & $X_{3}$ independent variables of the statistical model \\
$Y$ & variable response \\
\multicolumn{3}{|c}{ Greek } & letters \\
$\beta$ & parameters of the statistical model \\
$\mu_{\mathrm{max}}$ & maximum specific growth rate $\left(\mathrm{h}^{-1}\right)$ \\
\hline
\end{tabular}

estuary, Rio Grande do Sul State, Brazil $\left(32^{\circ} 01^{\prime} \mathrm{S}-52^{\circ} 05^{\prime} \mathrm{W}\right)$. Stock cultures were propagated and maintained on synthetic BGN medium [10] with the following composition: $\mathrm{K}_{2} \mathrm{HPO}_{4} \cdot 3 \mathrm{H}_{2} \mathrm{O}\left(0.040 \mathrm{gL}^{-1}\right), \mathrm{MgSO}_{4} \cdot 7 \mathrm{H}_{2} \mathrm{O}\left(0.075 \mathrm{~g} \mathrm{~L}^{-1}\right)$, EDTA $\left(0.001 \mathrm{~g} \mathrm{~L}^{-1}\right), \mathrm{H}_{3} \mathrm{BO}_{3}\left(2.860 \mathrm{gL}^{-1}\right), \mathrm{MnCl}_{2} \cdot 4 \mathrm{H}_{2} \mathrm{O}$ $\left(1.810 \mathrm{~g} \mathrm{~L}^{-1}\right), \mathrm{ZnSO}_{4} \cdot 7 \mathrm{H}_{2} \mathrm{O}\left(0.222 \mathrm{~g} \mathrm{~L}^{-1}\right), \mathrm{Na}_{2} \mathrm{MoO}_{4} \cdot 2 \mathrm{H}_{2} \mathrm{O}$ $\left(0.390 \mathrm{~g} \mathrm{~L}^{-1}\right), \quad \mathrm{CuSO}_{4} \cdot 5 \mathrm{H}_{2} \mathrm{O} \quad\left(0.079 \mathrm{~g} \mathrm{~L}^{-1}\right), \quad \mathrm{CaCl}_{2} \cdot 6 \mathrm{H}_{2} \mathrm{O}$ $\left(0.040 \mathrm{~g} \mathrm{~L}^{-1}\right), \mathrm{NaNO}_{3}\left(150 \mathrm{~g} \mathrm{~L}^{-1}\right) \mathrm{C}_{6} \mathrm{H}_{8} \mathrm{O}_{7} \cdot \mathrm{H}_{2} \mathrm{O}\left(0.006 \mathrm{~g} \mathrm{~L}^{-1}\right)$, ammonium and iron citrate $\left(0.006 \mathrm{~g} \mathrm{~L}^{-1}\right), \mathrm{pH}$ 8.0. The conditions used were $25^{\circ} \mathrm{C}, 1$ klux of light intensity and a photoperiod of $12 \mathrm{~h}$.

\subsection{Photobioreactor}

The diagram of the experimental apparatus used in this study is shown in Fig. 1. Measurements were made in a bubble column photobioreactor. The system was built in $4 \mathrm{~mm}$ thick glass, an internal diameter of $7.5 \mathrm{~cm}$, height of $75 \mathrm{~cm}$ and nominal working volume of $3.0 \mathrm{~L}$. The dispersion system for the reactor consisted of a $1.5 \mathrm{~cm}$ diameter air diffuser located in the centre of the column. The reactor was continuously illuminated with sixteen $20 \mathrm{~W}$ fluorescent lamps connected in parallel, located in a photoperiod chamber. Different numbers of lamps on each side of the photoperiod chamber were combined to give the desired light intensity. Airflow into the photobioreactor was provided via filtered air and pure $\mathrm{CO}_{2}$ cylinder through Teflon tubing. The $\mathrm{CO}_{2} /$ air mixture was adjusted to achieve the desired concentration of carbon dioxide in the airstream, through three rotameters that measured the flow rates of the carbon dioxide, the air and the mixture of gases, respectively.

\subsection{Obtaining and analysis of the kinetic data in an experimental photobioreactor}

The experiments were carried out in bioreactors operating with an intermittent regime, fed on $3.0 \mathrm{~L}$ synthetic BGN medium. The test conditions were: initial cell concentration of $100 \mathrm{mg} \mathrm{L}^{-1}$, isothermal reactor operating under different temperatures and light intensities and continuous aeration of
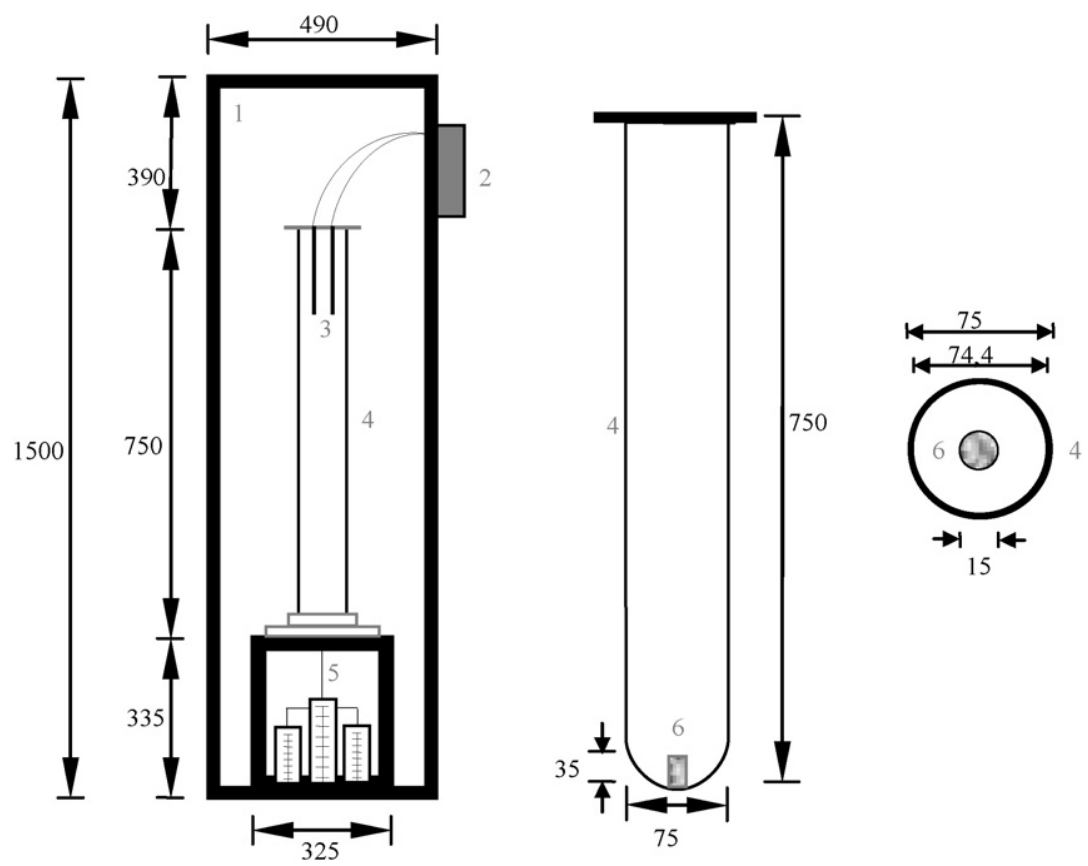

Fig. 1. Photobioreactor diagram. 1: Photoperiod chamber; 2: $\mathrm{pH}$, temperature and $\mathrm{CO}_{2}$ analyser; $3: \mathrm{pH}$, temperature and $\mathrm{CO}_{2}$ sensors; 4: photobioreactor; 5: system controlling the flow rate and mixture of the gases; 6: gas diffuser. All dimensions in mm. 
Table 1

Values of the independent variables for the different levels of the design

\begin{tabular}{llcrrrr}
\hline Independent variable & Symbol & Level & & & \\
\cline { 3 - 7 } & & -1.68 & -1 & 0 & 1 & +1.68 \\
\hline Temperature $\left({ }^{\circ} \mathrm{C}\right)$ & $X_{1}$ & 21.5 & 25 & 30 & 35 & 38.5 \\
Light intensity (klux) & $X_{2}$ & 0.96 & 3 & 6 & 9 & 11 \\
$\mathrm{CO}_{2}$ concentration $(\%)$ & $X_{3}$ & 3 & 15 & 25 & 50 & 62 \\
\hline
\end{tabular}

$3 \mathrm{~L} \mathrm{~min}^{-1}$ of air supplemented with $\mathrm{CO}_{2}$. The cell concentration was monitored every $12 \mathrm{~h}$ during the microbial growth phases. Residence times of up to $156 \mathrm{~h}$ were considered for all the experiments.

Response surface methodology was used to determine the optimal conditions for carbon fixation as a function of three experimental factors (temperature, light intensity and concentration of carbon dioxide enriched air). This methodology is widely used for controlling the effects of parameters in many processes. Its usage decreases the number of experiments, reducing time and material resources. Furthermore, the analysis performed on the results is easily carried out and experimental errors are minimized. The statistical method measures the effects of changes in operating variables and their mutual interactions on the process by way of an experimental design. The three steps used in the experimental design included statistical design experiments, estimation of coefficient using a mathematical model and an analysis of model applicability [11].

A five level, central composite design was used to evaluate the relationship between the culture conditions (independent variables) and the carbon fixation rate (dependent variable). Three replicates at the central point were used to estimate the experimental error.

The experimental design and the statistical analyses were carried out using the Statistica 7.0 software (Statsoft, USA). Table 1 shows the levels of the experimental variables used:
For a 3-factor system, the statistical model is defined by Eq. (1):

$$
\begin{aligned}
Y= & \beta_{0}+\beta_{1} X_{1}+\beta_{2} X_{2}+\beta_{3} X_{3}+\beta_{11} X_{1}^{2}+\beta_{22} X_{2}^{2} \\
& +\beta_{33} X_{3}^{2}+\beta_{12} X_{1} X_{2}+\beta_{13} X_{1} X_{3}+\beta_{23} X_{2} X_{3}
\end{aligned}
$$

The process was optimised from an analysis of the experimental design initially proposed, carried out in triplicate.

The calculated cell biomass values were used to calculate the maximum cell concentration $\left(X_{\mathrm{m}}, \mathrm{mg} \mathrm{L}^{-1}\right)$, maximum specific growth rate $\left(\mu_{\max }, \mathrm{h}^{-1}\right)$ and generation time $\left(t_{\mathrm{g}}, \mathrm{h}\right)$. The carbon fixation rate was calculated from the elemental analysis of the biomass, as shown in Eq. (2) [12]:

$R_{\mathrm{C}}=C_{\mathrm{c}} \times\left(\frac{X_{\mathrm{m}}-X_{0}}{t-t_{0}}\right) \times\left(\frac{M_{\mathrm{CO}_{2}}}{M_{\mathrm{c}}}\right)$

\subsection{Analytical methods}

The cell concentration was evaluated gravimetrically by filtering a known volume of culture medium through a $0.45 \mu \mathrm{m}$ filter and drying at $60^{\circ} \mathrm{C}$ for $24 \mathrm{~h}$. The measurements of light intensity incident on the reactor were carried out on the external column surface using a digital luximeter (Minipa MLM 1010). The temperature was controlled using thermostats, and measured using a polarographic sensor (Mettler Toledo lnPro5000 series). The flow rates of the carbon dioxide, air and $\mathrm{CO}_{2}$ enriched air were determined using rotameters (AFSG 100 Key Instruments). The elemental composition of the Aphanothece microscopica Nägeli cells was determined using a Perkin Elmer $2400 \mathrm{CHNS} / \mathrm{O}$ element analyser. Two-milligram samples of biomass were oxidised at $1000{ }^{\circ} \mathrm{C}$ and the resulting gases were determined using a thermal conductivity probe for carbon, nitrogen and hydrogen. The standard used was acetanilide, with a composition of $71.09 \%$ carbon, $11.84 \%$ oxygen, $6.71 \%$ hydrogen and $10.36 \%$ nitrogen.

Table 2

\begin{tabular}{|c|c|c|c|c|c|c|c|}
\hline \multicolumn{4}{|c|}{ Condition } & \multicolumn{4}{|c|}{ Kinetic parameter } \\
\hline$X_{1}\left({ }^{\circ} \mathrm{C}\right)$ & $X_{2}$ (klux) & $X_{3}(\%)$ & $\mu_{\max }\left(\mathrm{h}^{-1}\right)$ & $R^{2}$ & $t_{\mathrm{g}}(\mathrm{h})$ & $t_{\log }(\mathrm{h})$ & $X_{\mathrm{m}}\left(\mathrm{mg} \mathrm{L}^{-1}\right)$ \\
\hline 35.0 & 3 & 15 & 0.027 & 0.99 & 25.67 & 60 & 1672 \\
\hline 35.0 & 9 & 15 & 0.034 & 0.94 & 20.38 & 72 & 3000 \\
\hline 35.0 & 9 & 50 & 0.025 & 0.97 & 27.72 & 72 & 600 \\
\hline 35.0 & 3 & 50 & 0.022 & 0.99 & 31.50 & 72 & 500 \\
\hline 25.0 & 3 & 15 & 0.010 & 0.97 & 69.31 & 36 & 270 \\
\hline 25.0 & 9 & 15 & 0.013 & 0.90 & 53.31 & 108 & 455 \\
\hline 25.0 & 3 & 50 & 0.023 & 0.98 & 30.13 & 108 & 600 \\
\hline 25.0 & 9 & 50 & 0.023 & 0.98 & 30.13 & 96 & 905 \\
\hline 21.5 & 6 & 25 & 0.024 & 0.99 & 28.88 & 84 & 730 \\
\hline 38.5 & 6 & 25 & 0.003 & 0.98 & 231.1 & 36 & 230 \\
\hline 30.0 & 11 & 25 & 0.030 & 0.98 & 23.10 & 72 & 2300 \\
\hline 30.0 & 0.96 & 25 & 0.008 & 0.94 & 86.64 & 72 & 360 \\
\hline 30.0 & 6 & 62 & 0.023 & 0.98 & 30.13 & 72 & 1135 \\
\hline 30.0 & 6 & 3 & 0.021 & 0.97 & 33.01 & 48 & 1600 \\
\hline 30.0 & 6 & 25 & 0.028 & 0.99 & 24.75 & 108 & 1760 \\
\hline
\end{tabular}

Kinetic parameters for Aphanothece microscopica Nägeli 


\section{Results and discussion}

\subsection{Preliminary tests}

Fig. 2 shows representative growth curves for the cyanobacterium Aphanothece microscopica Nägeli under the different photosynthetic culture conditions. A comparison of the growth curves shows the lack of an adaptation phase for this microorganism, reaching the logarithmic growth phase as from $12 \mathrm{~h}$ of cultivation, followed by a stationary phase, and, under some conditions, a declining phase. According to Guerrero et al. [13], the absence of an adaptation phase in microalgal growth curves
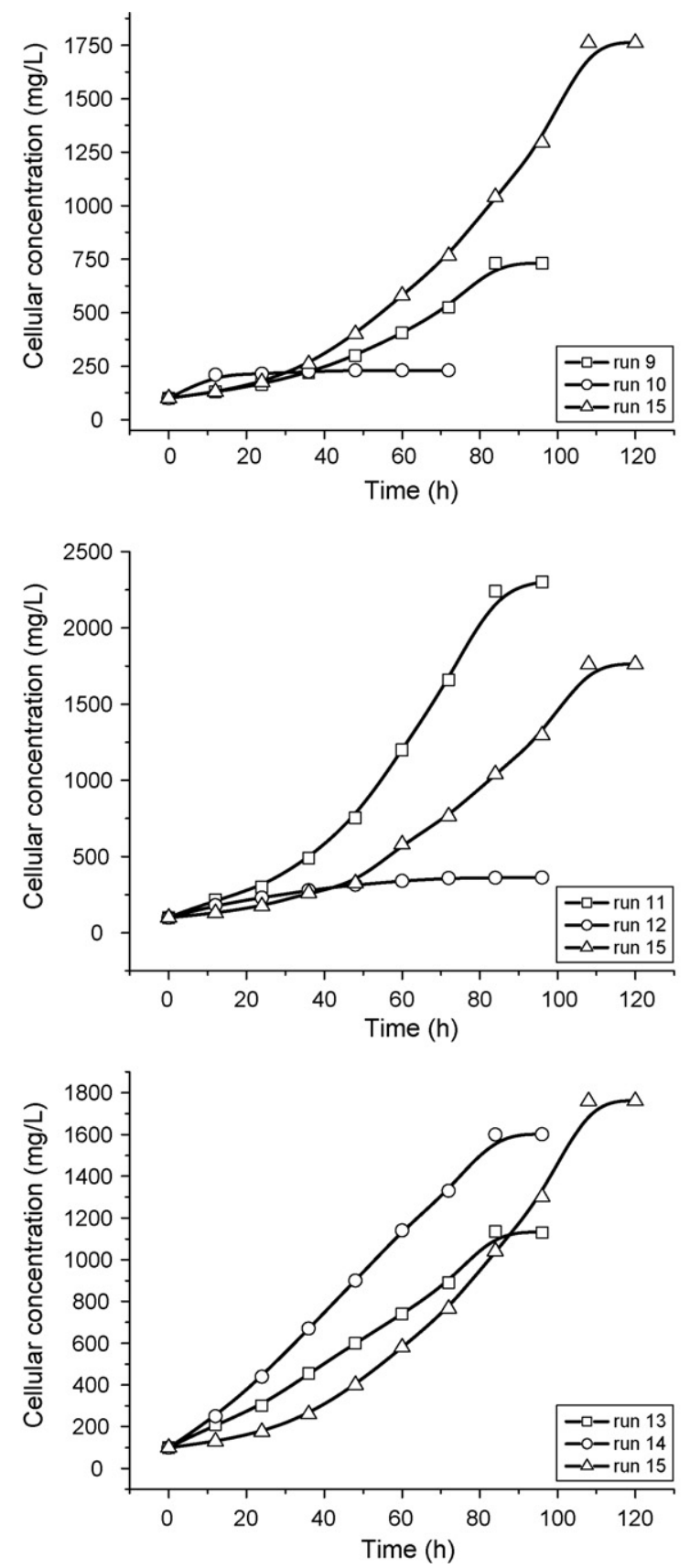

is characteristic of culture media with high carbon and inorganic nutrient availability. For all the cultures, after a maximum residence time of 5 days, the growth curves already indicated characteristics of the stationary phase, the maximum cell densities being obtained in this period. Similar results were obtained by Yue and Chen [14] and Hsueh et al. [15] in the photosynthetic cultivation of the microalgae Chlorella ZY-1 and Nannochlopsis oculta, obtaining positive growth rates in residence times below $120 \mathrm{~h}$.

Table 2 shows the growth kinetics of Aphanothece microscopica Nägeli. An analysis of these results shows that the maximum specific growth rates were obtained at $35^{\circ} \mathrm{C}, 9$ klux and $15 \%$
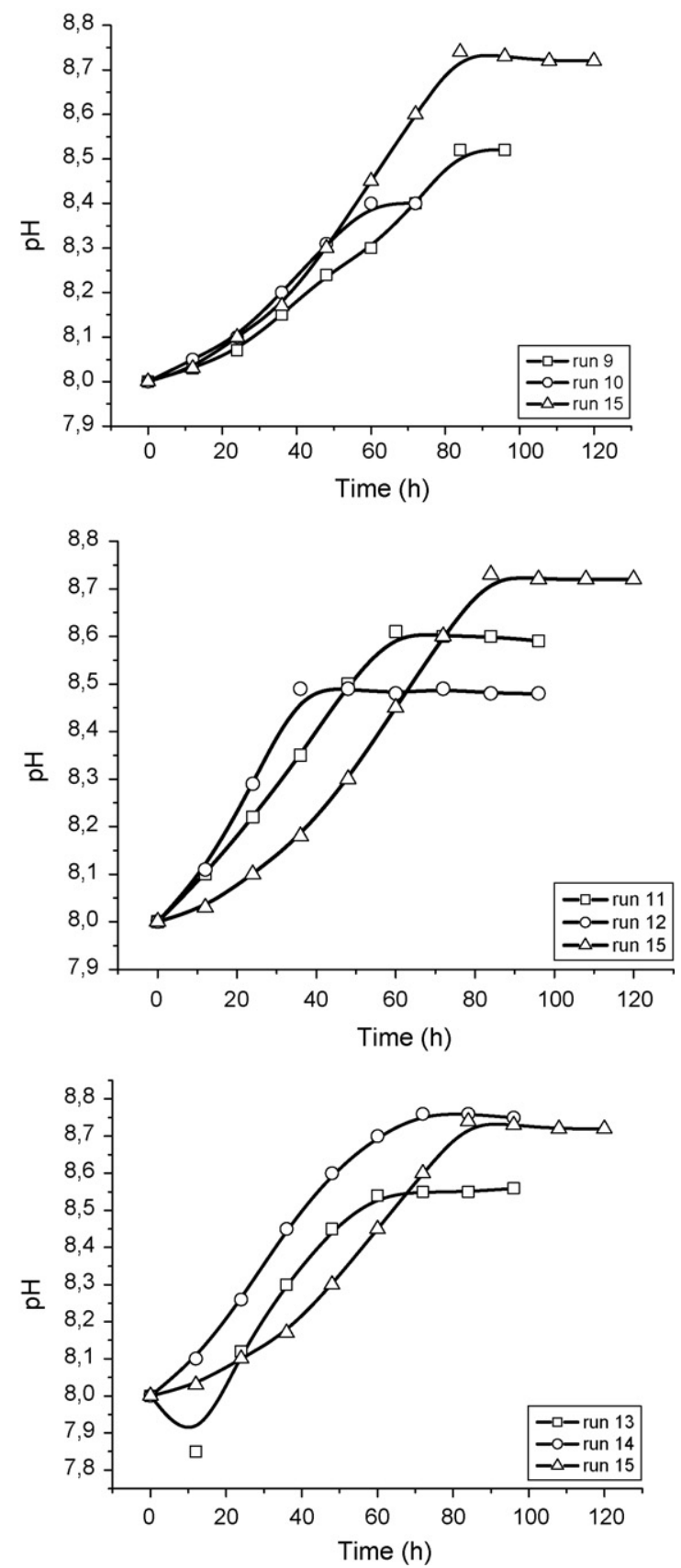

Fig. 2. Representative growth and $\mathrm{pH}$ curves as a function of temperature, light intensity and $\mathrm{CO}_{2}$ concentration. Effect of temperature (run 9 , 10 and 15 ); Effect of light intensity (run 11, 12 and 15) and effect of carbon dioxide concentration (run 13, 14 and 15). 
$\mathrm{CO}_{2}$, not differing significantly, according to the Tukey test $(\mathrm{p}<0.05)$, from the cultures grown at $30^{\circ} \mathrm{C}, 11 \mathrm{klux}$ and $25 \%$ $\mathrm{CO}_{2}$. The maximum values obtained for $\mu_{\max }$ were similar to those obtained by other authors for the species Euglena gracilis and Anabaena variabilis, cultivated using photosynthetic metabolism [16,17]. However the maximum concentration of carbon dioxide enrichment used for these cultures was $13 \%$ (v/v), suggesting that the Aphanothece microscopica Nägeli is more tolerant to gases enriched with high levels of $\mathrm{CO}_{2}$, since high growth rates were obtained with up to $62 \%(\mathrm{v} / \mathrm{v})$ of carbon dioxide. With respect to the generation times, a variation between 23.1 and $231.1 \mathrm{~h}$ was observed, as a function of the different cultivation conditions, indicating a dependence of cell growth on the conditions of temperature, light intensity and concentration of carbon dioxide enriched air in the operation of the photobioreactor. The logarithmic growth phases, determined by linear regression of the data, indicated exponential growth between 35 and $108 \mathrm{~h}$. The maximum cell density of $3.0 \mathrm{~g} \mathrm{~L}^{-1}$, was obtained by cultivating in air enriched with $15 \%$ carbon dioxide at a temperature of $35^{\circ} \mathrm{C}$, with a light intensity of 9 klux. Of the conditions evaluated, the results suggest these experimental conditions as the most adequate to produce biomass by the cyanobacterium Aphanothece microscopica Nägeli.

Cell growth associated with carbon dioxide assimilation from the medium coincided with an increase in $\mathrm{pH}$ values. Fig. 2 shows the representative variation in $\mathrm{pH}$ of the culture medium as a function of residence time. The $\mathrm{pH}$ range observed in the culture medium varied from 6.0 to 9.9 , indicating that the species $\mathrm{HCO}_{3}{ }^{-}$was the predominant form of carbon in the cultures.

The gradual increase in $\mathrm{pH}$ of the culture media, independent of the conditions, indicated that cultivation occurred in an alkaline $\mathrm{pH}$ range. Reductions in the initial $\mathrm{pH}$ value of the culture medium were only observed when cultivated with carbon dioxide concentrations equal or greater than $50 \%$. On the other hand, the highest $\mathrm{pH}$ values (9.9) were found for the cultures with the highest cell densities $\left(3.0 \mathrm{~g} \mathrm{~L}^{-1}\right)$, suggesting predominance of the photosynthetic metabolism of the microorganism under the experimental conditions used. According to Arnon [18] and Zuber [19], the increase in $\mathrm{pH}$ in photosynthetic cultures is an indication of the consumption of inorganic carbon due to cell growth. These authors reported that the increment in $\mathrm{pH}$ in the culture medium could be attributed to two main mechanisms: firstly the transport of hydroxide ions to outside the cell occurs by way of a reaction catalysed by the enzyme carbon anhydrase during the conversion of bicarbonate ions inside the cell to provide $\mathrm{CO}_{2}$ for the photosynthetic reaction, raising the $\mathrm{pH}$ of the culture medium. A second potential mechanism would be the increase in $\mathrm{pH}$ due to activity of the enzyme ribulose 1,5-bisphosphate carboxylase, whose activity is considerably dependent on $\mathrm{pH}$, increasing with increase in $\mathrm{pH}$. This enzyme is present in the photosynthetic apparatus of the cyanobacteria, where the $\mathrm{H}^{+}$ions are sequestered to the inside of the tylacoid membrane with a simultaneous transfer of $\mathrm{Mg}^{2+}$ to the environment. These light energy induced fluxes result in an increase in $\mathrm{pH}$ and in the $\mathrm{Mg}^{2+}$ concentration, activating the RubisCO enzyme and resulting in efficient carbon dioxide fixation.

An analysis of the elements in the Aphanothece microscopica Nägeli cells at the end of cultivation showed that $1 \mathrm{~g}$ of biomass could contain between 0.48 and $0.52 \mathrm{~g}$ of carbon as a function of the cultivation conditions used. These values were used to estimate the carbon fixation rates (Table 3).

Table 4 shows the results for the effects of and the interactions between the factors of temperature, light intensity and carbon dioxide concentration, as also the coefficients of the model. An analysis of this table shows that in the range evaluated, the carbon fixation rate was controlled by the factors of light intensity $(\mathrm{L})$, temperature $(\mathrm{Q})$, interaction between temperature $(\mathrm{L})$ and carbon dioxide concentration (L), and by the carbon dioxide concentration (L), in this order of importance. The other factors and interactions showed a lower proportion of statistical importance.

Table 3

Coded matrix of the effects of temperature, light intensity and $\mathrm{CO}_{2}$ concentration on the carbon fixation rate

\begin{tabular}{|c|c|c|c|c|}
\hline Run & Temperature $\left(X_{1}\right)$ & Light intensity $\left(X_{2}\right)$ & $\mathrm{CO}_{2}\left(X_{3}\right)$ & $R_{\mathrm{C}}\left(\mathrm{mg} \mathrm{L}^{-1} \mathrm{~h}^{-1}\right)$ \\
\hline 1 & +1 & -1 & -1 & 24.80 \\
\hline 2 & +1 & +1 & -1 & 45.78 \\
\hline 3 & +1 & +1 & +1 & 11.84 \\
\hline 4 & +1 & -1 & +1 & 11.36 \\
\hline 5 & -1 & -1 & -1 & 3.45 \\
\hline 6 & -1 & +1 & -1 & 6.30 \\
\hline 7 & -1 & -1 & +1 & 8.88 \\
\hline 8 & -1 & +1 & +1 & 16.30 \\
\hline 9 & -1.68 & 0 & 0 & 12.78 \\
\hline 10 & +1.68 & 0 & 0 & 4.61 \\
\hline 11 & 0 & +1.68 & 0 & 39.07 \\
\hline 12 & 0 & -1.68 & 0 & 6.15 \\
\hline 13 & 0 & 0 & +1.68 & 21.01 \\
\hline 14 & 0 & 0 & -1.68 & 30.44 \\
\hline 15 & 0 & 0 & 0 & 26.20 \\
\hline 16 & 0 & 0 & 0 & 25.96 \\
\hline 17 & 0 & 0 & 0 & 26.04 \\
\hline
\end{tabular}


Table 4

Coefficients of the model estimated by linear regression

\begin{tabular}{|c|c|c|c|c|c|c|c|}
\hline \multirow[t]{2}{*}{ Factor } & \multirow[t]{2}{*}{ Effects } & \multirow[t]{2}{*}{ Standard error } & \multirow[t]{2}{*}{$t(2)$} & \multirow[t]{2}{*}{$p$} & \multirow[t]{2}{*}{ Coefficients } & \multicolumn{2}{|c|}{ Estimates per interval } \\
\hline & & & & & & $-95 \%$ & $+95 \%$ \\
\hline Mean & 26.22 & 0.07 & 372.47 & 0.00000 & 26.22 & 25.92 & 26.53 \\
\hline$X_{1}(\mathrm{~L})$ & 6.60 & 0.06 & 99.88 & 0.00010 & 3.30 & 3.16 & 3.44 \\
\hline$X_{1}(\mathrm{Q})$ & -13.39 & 0.07 & -183.95 & 0.00003 & -6.69 & -6.85 & -6.53 \\
\hline$X_{2}(\mathrm{~L})$ & 12.75 & 0.06 & 192.85 & 0.00002 & 6.37 & 6.23 & 6.51 \\
\hline$X_{2}(\mathrm{Q})$ & -3.55 & 0.07 & -48.78 & 0.00042 & -1.77 & -1.93 & -1.61 \\
\hline$X_{3}(\mathrm{~L})$ & -7.00 & 0.06 & -105.86 & 0.00008 & -3.50 & -3.64 & -3.35 \\
\hline$X_{3}(\mathrm{Q})$ & -1.34 & 0.07 & -18.52 & 0.00290 & -0.67 & -0.83 & -0.51 \\
\hline$X_{1}(\mathrm{~L}) \times X_{2}(\mathrm{~L})$ & 2.79 & 0.08 & 32.37 & 0.00095 & 1.39 & 1.21 & 1.58 \\
\hline$X_{1}(\mathrm{~L}) \times X_{3}(\mathrm{~L})$ & -15.70 & 0.08 & -181.72 & 0.00003 & -7.85 & -8.03 & -7.66 \\
\hline$X_{2}(\mathrm{~L}) \times X_{3}(\mathrm{~L})$ & -3.98 & 0.08 & -46.08 & 0.00047 & -1.99 & -2.17 & -1.80 \\
\hline
\end{tabular}

Eq. (3) represents the statistical model for the variable response carbon fixation rate:

$$
\begin{aligned}
Y= & 26.2+3.3 X_{1}-6.7 X_{1}^{2}+6.4 X_{2}-1.77 X_{2}^{2}-3.5 X_{3} \\
& -0.67 X_{3}^{2}+1.4 X_{1} X_{2}-7.85 X_{1} X_{3}-2.0 X_{2} X_{3}
\end{aligned}
$$

Contour curves (Fig. 3) show the variation in the carbon fixation rate as a function of the factors studied. Thus an increase in carbon fixation rate is obtained not only by fixing the light intensity at the highest level, that is, carrying out the cultivation under high light intensities, but also by fixing the temperature in the central region and the carbon dioxide concentration at the lowest level (reduced proportions of $\mathrm{CO}_{2}$ enrichment in the air entering the photobioreactor).

The carbon fixation rate varied from 3.45 to $45.78 \mathrm{mg} \mathrm{L}^{-1} \mathrm{~h}^{-1}$ under the different culture conditions. These results are higher than those obtained by Kajiwara et al. [12] when cultivating the cyanobacterium Synechoccus (PCC 7942) in photobioreactors at $30^{\circ} \mathrm{C}$ with 8 klux and air enriched with carbon dioxide at $5 \%$, obtaining maximum carbon fixation rates to the order of $25 \mathrm{mg} \mathrm{L}^{-1} \mathrm{~h}^{-1}$ and Yun et al. [20], who obtained rates of $23.4 \mathrm{mg} \mathrm{L}^{-1} \mathrm{~h}^{-1}$ for the microalga Chlorella vulgaris (UTEX 259) under conditions of $27^{\circ} \mathrm{C}, 15 \%$ of $\mathrm{CO}_{2}$ and $110 \mu \mathrm{E} \mathrm{m}^{-2} \mathrm{~s}^{-1}$.

These results reflect the adaptation of the microorganism under study to the experimental conditions, suggesting the importance of optimising the photobioreactor operational conditions in order to obtain higher rates of biological carbon fixation.

Different authors have reported the importance of the environmental conditions on the growth of cyanobacteria.
Parameters such as temperature, light intensity, $\mathrm{pH}$ and carbon dioxide concentration have been indicated as being of fundamental importance in the development of these microorganisms [21]. Thus it was shown that cultivation conditions in the temperature range from 30 to $35^{\circ} \mathrm{C}$, with $9-11$ klux and $15-25 \% \mathrm{CO}_{2}$, favoured cell growth, associated with carbon fixation. These results agreed with those of Munoz and Guieysse [22], who reported that the efficiency of systems using microalgae normally decreased at low and higher temperatures, justifying the low cell performance of the cultures incubated at 21.5 and $38.5^{\circ} \mathrm{C}$, when compared to those incubated at $30^{\circ} \mathrm{C}$ under the same conditions of light intensity and $\mathrm{CO}_{2}$ concentration. According to Grossman et al. [23], the optimum temperature range for the development of cyanobacteria is from 25 to $35^{\circ} \mathrm{C}$.

With respect to light intensity, it was shown that the maximum intensity used was insufficient to promote the phenomenon of cell photoinhibition, since even at $11 \mathrm{klux}$ high growth rates were recorded. On the other hand, at 0.96 klux there was a pronounced reduction in cell growth, suggesting limitation of the energy required for the sequence of photosynthetic reactions that would result in carbon fixation under these conditions.

The effect of different carbon dioxide concentrations in the gases entering the photobioreactor was analysed by Yue and Chen [14], who found photosynthetic activity for concentrations of up to $70 \%(\mathrm{v} / \mathrm{v})$ enrichment of the air with $\mathrm{CO}_{2}$, which is usually the main source of carbon in photosynthetic cultures of cyanobacteria. According to Cuaresma et al. [24], the way in which cyanobacteria adapt themselves to use $\mathrm{CO}_{2}$ as the carbon source is related to the carbon concentration mechanisms (CCM). The photosynthetic mechanism developed

Table 5

Analysis of variance (ANOVA) for the quadratic model

\begin{tabular}{lccc}
\hline Source of variation & Sum of squares & Degrees of freedom & Mean squared \\
\hline Regression & 1938.8 & 9 & 215.42 \\
Residues & 532.66 & 7 & 76.09 \\
Lack of fit & 532.63 & 5 & $2.83^{\text {a }}$ \\
Pure error & 0.03 & 2 & 106.52 \\
Total & 2741.44 & 16 & 0.015 \\
\hline
\end{tabular}

\footnotetext{
a Statistical significance $(p<0.1)$.
} 

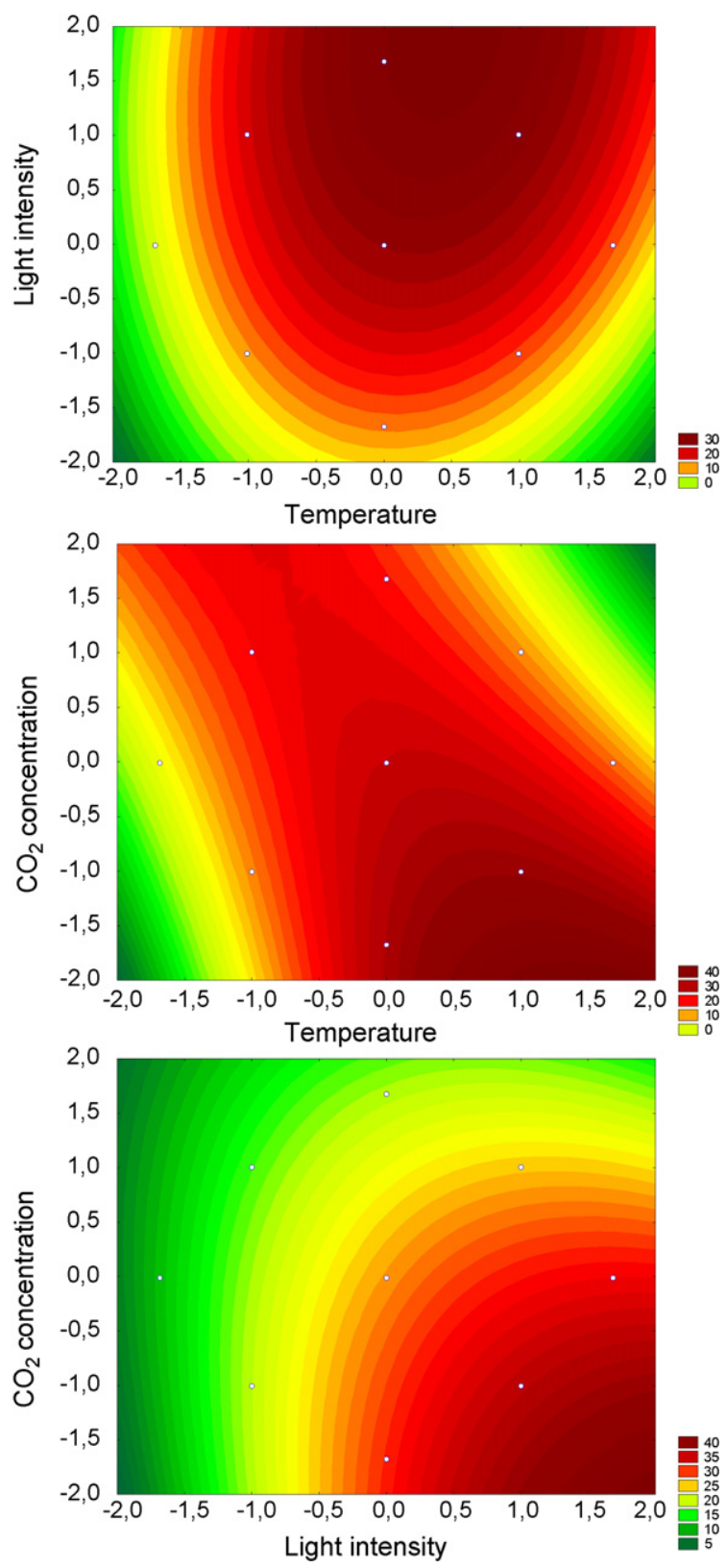

Fig. 3. Contour curves for the variable carbon fixation rate.

by these organisms allowed for the transport of free $\mathrm{CO}_{2}$ and of bicarbonate ions through a fine plasmatic membrane, being accumulated in the cell as a carbon reservoir, making it possible to assimilate inorganic carbon in the form of bicarbonate or free carbon dioxide. With respect to cell growth and carbon fixation rate, the best results were obtained with air enriched with $15 \% \mathrm{CO}_{2}$, reduced efficiency of the photobioreactor being observed with flow rates below or above $0.45 \mathrm{~L}_{\mathrm{CO} 2} \mathrm{~min}^{-1}$.

The model was validated from the $F$ distribution (Table 5), which suggested the existence of a quadratic relationship between the variables, indicating that the proposed model fitted the experimental data. The statistical model obtained explained a maximum of $99.99 \%$ of the variation.
Table 6

Kinetic parameters for process optimization

\begin{tabular}{lc}
\hline Kinetic variable & Value $^{\mathrm{a}}$ \\
\hline$\mu_{\max }\left(\mathrm{h}^{-1}\right)$ & 0.04 \\
$t_{\mathrm{g}}(\mathrm{h})$ & 17.3 \\
$t_{\log }(\mathrm{h})$ & 120 \\
$X_{\mathrm{m}}\left(\mathrm{mg} \mathrm{L}^{-1}\right)$ & 5100 \\
$R_{\mathrm{C}}\left(\mathrm{mg} \mathrm{L}^{-1} \mathrm{~h}^{-1}\right)$ & 109.2
\end{tabular}

${ }^{a}$ Mean of three replicates are shown.

\subsection{Process optimisation}

As from the statistical model and an analysis of the contour diagrams, which suggested a displacement of the operational conditions to the region of high light intensities (11 klux), maintaining the conditions of temperature at $35^{\circ} \mathrm{C}$ and injection of air enriched with $15 \% \mathrm{CO}_{2}$, cultures were carried out under these conditions in order to optimise the fixation of carbon by the cyanobacterium Aphanothece microscopica Nägeli. Table 6 shows the kinetic parameters obtained for the process under these conditions. A significant increase in the kinetic variables of growth and carbon fixation was observed, obtaining carbon fixation rates $58.1 \%$ higher than those obtained under the best conditions initially evaluated ( $9 \mathrm{klux}, 35^{\circ} \mathrm{C}, 15 \%$ of $\mathrm{CO}_{2}$ ), showing the importance of the factors studied and the adjustment of the methodology used.

\section{Conclusions}

The carbon dioxide concentration, temperature and light intensity are determinant factors in the carbon fixation process by the cyanobacterium Aphanothece microscopica Nägeli.

Under operational conditions of $11 \mathrm{klux}, 35^{\circ} \mathrm{C}$ and $15 \% \mathrm{CO}_{2}$, the microorganism performed better, obtained maximum specific growth rates and carbon fixation rates of $0.04 \mathrm{~h}^{-1}$ and $109.2 \mathrm{mg} \mathrm{L}^{-1} \mathrm{~h}^{-1}$, respectively.

Response surface methodology was adequate to determine the effects of the factors and optimise the process.

Thus the results obtained in the present study suggest the potential of applying this type of process to obtain carbon credits. Nevertheless one must remember that the definition of the ideal process conditions only helps in terms of the magnitude of the variables involved in the system, with the objective of applying the process under complex real conditions. In addition, the carbon fixed in the biomass only represents a fraction of the total carbon dioxide transformed by the system.

\section{Acknowledgements}

Funding for this research was provided by the Fundação de Amparo a Pesquisa no Estado de São Paulo - FAPESP (Brazil) and by the ALFA Programme, II-0259-FA-FC - POLYLIFE (European Union). The authors are grateful to Dra. Maria Isabel Queiroz (Fundação Universidade Federal do Rio Grande) for providing the microalgal cultures. 


\section{References}

[1] H. Yamada, N. Ohkuni, S. Kajiwara, K. Ohtaguchi, $\mathrm{CO}_{2}$-removal characteristics of Anacystis nidulans R2 in airlift bioreactors, Energy 22 (1997) 349-352.

[2] H.W. Yen, D.E. Brune, Anaerobic co-digestion of algal sludge and waste paper to produce methane, Bioresour. Technol. 98 (2007) 130-134.

[3] Y. Chisti, Biodiesel from microalgae, Biotechnol. Adv. 25 (2007) 294-306

[4] B.D. Lee, W.A. Apel, M.R. Walton, Calcium carbonate formation by Synechococcus sp. strain PCC 8806 and Synechococcus sp. strain PCC 8807, Bioresour. Technol. 97 (2006) 2427-2434.

[5] E. Jacob-Lopes, C.H.G. Scoparo, T.T. Franco, Rates of $\mathrm{CO}_{2}$ removal by Aphanothece microscopica Nägeli in tubular photobioreactors, Chem. Eng. Process., doi:10.1016/j.cep.2007.06.004.

[6] F.A. Esteves, in: Rio de Janeiro (Ed.), Fundamentos de limnologia, Internacional, 1988.

[7] E. Jacob-Lopes, L.Q. Zepka, L.A.A. Pinto, M.I. Queiroz, Characteristics of thin-layer drying of the cyanobacterium Aphanothece microscopica Nägeli, Chem. Eng. Process. 46 (2006) 63-69.

[8] M.I. Queiroz, E. Jacob-Lopes, L.Q. Zepka, R. Bastos, R. Goldbeck, The kinetics of the removal of nitrogen and organic matter from parboiled rice effluent by cyanobacteria in a stirred batch reactor, Bioresour. Technol. 98 (2007) 2163-2169.

[9] L.Q. Zepka, E. Jacob-Lopes, R. Goldbeck, M.I. Queiroz, Production and biochemical profile of the microalgae Aphanothece microscopica Nägeli submitted to different drying conditions, Chem, Eng, Process., doi:10.1016/j.cep.2007.04.013.

[10] R. Rippka, J. Deruelles, J.B. Waterbury, M. Herdman, R.Y. Stanier, Generic assignments strain histories and properties of pure cultures of cyanobacteria, J. Gen. Microbiol. 111 (1979) 1-61.

[11] G.E.P. Box, W.G. Hunter, J.S. Hunter, Statistics for Experiments, John Wiley and Sons, New York, 1978.

[12] S. Kajiwara, H. Yamada, O. Narumasa, Design of the bioreactor for carbon dioxide fixation by Synechococcus PCC7942, Energy Conv. Manage. 38 (1997) 529-532.
[13] L. Guerrero, F. Omil, R. Mendez, J.M. Lema, Anaerobic hydrolysis and acidogenesis of wastewaters from food industries with high content of organic solids and protein, Water Res. 33 (15) (1999) 3250-3281.

[14] L. Yue, W. Chen, Isolation and determination of cultural characteristics of a new highly $\mathrm{CO}_{2}$ tolerant fresh water microalgae, Energy Conv. Manage. 46 (2005) 1846-1896.

[15] H.T. Hsueh, H. Chu, S.T. Yu, A batch study on the bio-fixation of carbon dioxide in the absorbed solution from a chemical wet scrubber by hot springs and marine algae, Chemosphere 66 (2007) 878-886.

[16] S.R. Chae, E.J. Hwang, H.S. Shin, Single cell protein production of Euglena gracilis and carbon dioxide fixation in an innovative photo-bioreactor, Bioresour. Technol. 97 (2006) 322-329.

[17] J.H. Yoon, High cell density culture of Anabaena variabilis using repeated injections of carbon dioxide for the production of hydrogen, Int. J. Hydrogen Energy 27 (2002) 1265-1270.

[18] H. Zuber, Structure of light-harvesting antenna complexes of photosynthetic bacteria, cyanobacteria and red algae, Trends Biochem. Sci. 11 (1986) 414-419.

[19] D.I. Arnon, The discovery of photosynthetic phosphorylation, Trends Biochem. Sci. 9 (1984) 258-262.

[20] Y.S. Yun, S.B. Lee, J.M. Park, C. Lee, J. Yang, Carbon dioxide fixation by algal cultivation using wastewater nutrients, J. Chem. Technol. Biotechnol. 69 (1997) 451-455.

[21] G. Subramanian, N. Thajuddin, Cyanobacterial biodiversity and potential applications in biotechnology, Curr. Sci. 89 (2005) 47-57.

[22] R. Muñoz, B. Guieysse, Algal-bacterial processes for the treatment of hazardous contaminants: a review, Water Res. 40 (2006) 2799-2815.

[23] A.R. Grossman, M.R. Schaefer, G.G. Chiang, J.L. Collier, The responses of cyanobacteria to environmental conditions: light and nutrients, in: D.A. Bryant (Ed.), The Molecular Biology of cyanobacteria, Kluwer Academic Plubishers, 1994, pp. 641-668.

[24] M. Cuaresma, I. Garbayo, J.M. Vega, C. Vílchez, Growth and photosynthetic utilization of inorganic carbon of the microalga Chlamydomonas acidophila isolated from Tinto river, Enzyme Microb. Technol. 40 (2006) $158-162$. 